\title{
Biodiversity of the metazoan parasites of Prochilodus lineatus (Valenciennes, 1837) (Characiformes: Prochilodontidae) in anthropized environments from the Batalha River, São Paulo State, Brazil
}

\author{
Lucas Aparecido Rosa Leite', Larissa Sbeghen Pelegrini', Beatriz Narciso Agostinho², \\ Rodney Kozlowiski de Azevedo ${ }^{2}$ \& Vanessa Doro Abdallah ${ }^{2}$ * (10 \\ 'Universidade Estadual Paulista "Júlio de Mesquita Filho”, Instituto de Biociências, Botucatu, SP, Brasil \\ ${ }^{2}$ Universidade do Sagrado Coração, Pró-reitoria de Pesquisa e Pós-graduação, Bauru, SP, Brasil \\ *Corresponding author: Vanessa Doro Abdallah, e-mail:vanessaabdallahusc@gmail.com
}

\begin{abstract}
LEITE, L. A. R.; PELEGRINI, L. S.; AGOSTINHO, B. N.; AZEVEDO, R. K.; ABDALLAH, V. D. Biodiversity of the metazoan parasites of Prochilodus lineatus (Valenciennes, 1837) (Characiformes: Prochilodontidae) in anthropized environments from the Batalha River, São Paulo State, Brazil. Biota Neotropica. 18(3): e20170422. http://dx.doi.org/10.1590/1676-0611-BN-2017-0422
\end{abstract}

\begin{abstract}
Biodiversity of fish parasites is a field of significant growth worldwide, whether due to the advancement of fish farms or the important role of these organisms as indicators of environment quality and ecosystem health, making them useful tools in the conservation and maintenance of the biodiversity as a whole. The objectives of this study were to evaluate the structure and composition of the parasitic fauna of Prochilodus lineatus collected from two structurally distinct stretches of the Batalha River. Fifty specimens of $P$. lineatus were collected between June 2015 and June 2016. Of these 50 hosts, 875 parasite specimens were collected, divided into 30 species, belonging to seven groups: Myxozoa, Monogenea, Digenea, Acanthocephala, Nematoda, Copepoda and Hirudinea. In addition to new records of known parasites of $P$. lineatus for this locality, 13 species were newly recorded parasitizing this fish, including a new monogenean species (Tereancistrum sp. n.), with Monogenea being the most representative class in the study. The findings of this study expands the known geographic distribution of these parasite species and helps to increase the knowledge of the biodiversity of these organisms in different hosts and environments. In general, the structure and composition of the $P$. lineatus parasitic fauna did not seem to be influenced by the structural characteristics of the two stretches studied, due to the migratory habits of the host.

Keywords: Parasitic diversity, Curimbatá, Lentic ecosystems, Lotic ecosystems, Tietê-Batalha River basin.

\section{Biodiversidade dos metazoários parasitos de Prochilodus lineatus (Valenciennes, 1837) (Characiformes: Prochilodontidae) em ambientes antropizados no rio Batalha, Estado de São Paulo, Brasil}

Resumo: A biodiversidade de parasitos de peixes é um campo de pesquisa com significativo crescimento mundial, seja pelo aumento das pisciculturas ou pelo importante papel desses organismos como indicadores da qualidade do ambiente e da saúde do ecossistema, tornando-os importantes ferramentas na conservação e manutenção da biodiversidade como um todo. O objetivo desse estudo foi de avaliar a estrutura e composição da fauna parasitária de Prochilodus lineatus coletados em dois trechos estruturalmente distintos do rio Batalha. Cinquenta espécimes de $P$. lineatus foram coletados entre junho de 2015 e junho de 2016. Desses 50 hospedeiros, foram coletados 875 espécimes de parasitos, divididos em 30 espécies, pertencentes a sete grupos: Myxozoa, Monogenea, Digenea, Acanthocephala, Nematoda, Copepoda e Hirudinea. Além dos novos registros para a localidade com parasitos já observados parasitando $P$. lineatus anteriormente, obteve-se o novo registro de 13 espécies parasitando este peixe, além do registro de uma nova espécie de monogenético (Tereancistrum $\mathrm{sp}$. n.). Os achados desse estudo expandem a distribuição geográfica dessas espécies de parasitos e ajudam a aumentar o conhecimento da biodiversidade desses organismos em diferentes hospedeiros e ambientes. De modo geral, a estrutura e composição da fauna parasitária de $P$. lineatus não pareceu ser influenciada por características estruturais dos dois trechos estudados, devido aos hábitos migratórios do hospedeiro.

Palavras-chave: Diversidade parasitária, Curimbatá, Ecossistemas lênticos, Ecossistemas lóticos, bacia hidrográfica do Tietê-batalha. 


\section{Introduction}

The tropics have an extensive diversity of plants and animals, with a large number of species and highly complex interactions when compared with temperate zones. The fish fauna follows this general ecological rule, both in aspects of taxonomy as well as in occupation and distribution in the environment (Lowe-McConnel 1999).

The fishes are the most diverse group of vertebrates, comprising at least 32,500 current known species, found in almost any type of aquatic environment and presenting enormous diversity in morphology, habitat occupation and biology (Nelson 2006, Rosa \& Lima 2008). It is estimated that 13,000 species of fish live in strictly freshwater environments, and the tropics are the greatest maintainers of freshwater fish biodiversity on the planet, sheltering around 4,475 species, with the majority (2,587) in Brazilian territories alone (Langeani et al. 2009).

Even though vertebrate biodiversity in the neotropics has been studied extensively over the last four centuries (Rull 2011), there are still serious gaps in our knowledge of the biodiversity of invertebrates, particularly in parasitic faunas. Studies on parasitic biodiversity is extremely important, since parasitism plays a crucial role in an ecosystem's balance, regulating the abundance or density of host populations, stabilizing the trophic chains and structuring animal communities (Poulin \& Morand 2004). In addition, parasites can also be used as biomonitoring tools for environmental impacts, especially in aquatic environments, as they manifest themselves in the face of environmental changes much faster than their hosts (Lafferty 1997, Lafferty \& Kuris 2005, Silva-Souza et al. 2006, Sures 2008).

Biodiversity of fish parasites is a field of significant growth worldwide, whether due to the advancement of fish farms (Thatcher 2006), or the important role of these organisms as indicators of environment quality and ecosystem health, which are very useful tools in the conservation and maintenance of the biodiversity as a whole (Gómez \& Nichols 2013). Several studies on the biodiversity of fish parasites in Brazilian basins have been carried out in recent decades (Eiras et al. 2011).

Prochilodus lineatus (Valenciennes, 1837), popularly known as Curimbatá or Curimatã, is a native species to the upper Paraná River basin, occurring throughout South America, along the Paraná-Paraguay and Paraíba do Sul River basins (Argentina, Brazil, Paraguay and Uruguay). This species belongs to the family Prochilodontidae, in the order Characiformes (Castro \& Vari 2003). It is considered mediumsized and with migratory habits (Oyakawa et al. 2009). Its ecology and biology have been a consistent target of research as its populations have been constantly declining due to negative anthropic actions, such as dam construction and sport fishing (Rosa \& Lima 2008, Oyakawa et al. 2009).

As a host, this species has also been the subject of several parasitological studies (Eiras et al. 1995, Martins et al. 2001, Adriano et al. 2002, Takemoto et al. 2002, Eiras et al. 2004, Lizama et al. 2004, Adriano et al. 2005, Lizama et al. 2005, Santos et al. 2005, Lizama et al. 2006, Cugliana et al. 2009, Takemoto et al. 2009, Eiras et al. 2011, Valladão et al. 2014). However, relatively little is known about the parasitic fauna of $P$. lineatus in the region of the Tietê-Baltalha basin, particularly in the Batalha River, where there is no published data. This highlights the need for studies that complement previously obtained data, and that contribute satisfactory knowledge of the biodiversity of parasites in this species in different aquatic ecosystems.
Therefore, this study aimed to carry out an ecological study of parasitic biodiversity of $P$. lineatus in two stretches of the Batalha River, State of São Paulo, Brazil, with distinct limnologic and structural characteristics to verify if there are differences between the parasitic infracommunities in the two stretches.

\section{Material and Methods}

\section{Study area}

The present study was conducted in two stretches of the Batalha River (Figure 1), each with quite different structural and limnological characteristics. The distance between the two stretches is approximately $135 \mathrm{Km}$.

\section{Stretch 1 -River channel-Reginópolis (SP)}

The stretch of the Batalha River, located in the municipality of Reginópolis, State of São Paulo (21 $533^{\prime} 17^{\prime \prime}$ S and 49 13 '31'W), is an anthropic area with predominantly lotic characteristics.

The area around the river in this stretch, though covered by native riparian forest for most of its extent, it used substantially for agricultural purposes, particularly cattle breeding and sugar cane, corn and eucalyptus plantations, causing the quantities of organic matter and leachate pollutants to be quite high. In addition, the municipality does not have sewage treatment, causing sewage to be released in natura in a tributary of the river a river (Santos \& Heubel 2008, Estado de São Paulo 2010, Sistema Nacional de Informações sobre Saneamento 2016).

\section{Stretch 2-DAE's water catchment lagoon-Piratininga (SP)}

The water catchment lagoon of the Departamento de Água e Esgoto (DAE) is located in the municipality of Piratininga, State of São Paulo (22024'46”S and 49 $05^{\prime} 05^{\prime}$ 'W). It is a highly anthropized lentic ecosystem, with an area of approximately $170,000 \mathrm{~m}^{2}$ and a water volume of $1,256,040 \mathrm{~m}^{3} /$ month. Agriculture, livestock and industrial activities in areas adjacent to the lagoon have unleashed irreversible environmental impacts in its structure, leading to silting and reduction of the few remnants of native vegetation, in addition to contributing to the significant increase of pollutant levels (heavy metals, organochlorine compounds, free radicals etc.) and endangering water quality. Despite this, the responsible regulatory department considers the water drawn from the lagoon as Class 2, that is, good quality for domestic use, human consumption, aquatic biodiversity protection and recreation (Brasil 2005).

\section{Fish sampling}

Fish collections were carried out between June 2015 and June 2016 with a total of nine collections. Of these, three were carried out on the Batalha River stretch of the municipality of Piratininga (June 2015, February and June 2016) and six were carried out in the stretch located in the municipality of Reginópolis (May, June and August 2015, February, March and May 2016).

For fish collection, standardized experimental fishing methodology was used, using nylon monofilament holding nets, with different mesh sizes (from 2 to $10 \mathrm{~cm}$, alternate internodes) and variable heights. In each of the points the nets were installed perpendicularly and in half-moon, 

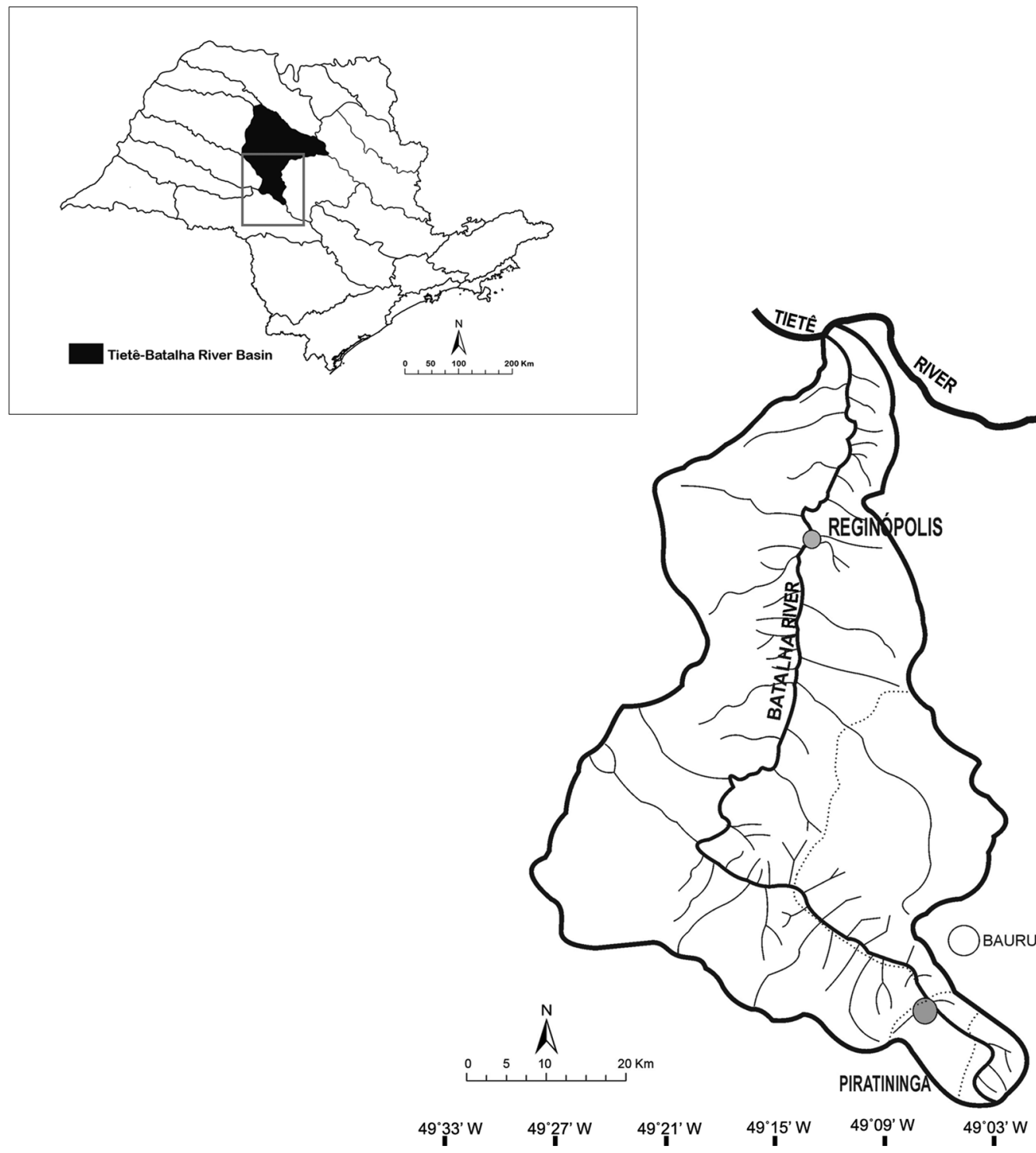

$22^{\circ} 03^{\prime} \mathrm{S}=$

$22^{\circ} 09^{\prime} \mathrm{S}=$

$22^{\circ} 15^{\prime} \mathrm{S}=$

$22^{\circ} 21^{\prime} \mathrm{S}=$

Figure 1. The Tietê-Batalha River Basin (BH-TB), located in the State of São Paulo, highlighting the course of the Batalha River between the two stretches studied, Reginópolis (SP) and Piratininga (SP).

at dusk (around 5pm) and the expense made at dawn (around 5am), resulting in approximately $12 \mathrm{~h}$ of exposure.

After collection, fishes that were still alive were anesthetized with eugenol-based solution and euthanized through the physical method of medullary section. They were then packed in individual plastic bags and transported to the laboratory where they were frozen until necropsy, where measures of total length $(\mathrm{cm})$, standard length $(\mathrm{cm})$, weight $(\mathrm{g})$ and sex were obtained. All collecting processes were made under the authorization of the Instituto Chico Mendes de Biodiversidade (ICMBio) through the Sistema de Autorização e Informação em Biodiversidade (SISBio) (authorization $n^{\circ}$ 40998-2). Additionally, the fish anesthesia and euthanasia methodologies were made following the guidelines of the Conselho Nacional de Controle de Experimentação Animal (CONCEA), and the research project was submitted to the Comitê de Ética no Uso de Animais (CEUA) da Universidade do Sagrado Coração (USC) (authorization $n^{\circ} 3295230615$ ) before it could be performed.

\section{Parasite sampling, processing and identification}

For ectoparasite collection, the body, fins, nostrils, mouth, eyes and inner face of the operculums of each fish were separately washed with water and the contents of each external organ was filtered in a $53-\mu \mathrm{m}$ mesh sieve. After this step, the gills were withdrawn and also submerged in aqueous solution and the vessel was shaken approximately 50 times and the contents passed through a 53- $\mu \mathrm{m}$ sieve. Afterwards, all the collected contents of the external organs were placed in Petridishes and analyzed individually under a stereomicroscope for parasite collection (modified from Eiras et al. 2006).

Then, through a longitudinal incision on the ventral surface of each individual, all organs were removed and separated. The visceral cavity and each organ were washed and filtered through a $75-\mu \mathrm{m}$ mesh sieve, then placed in Petri dishes and examined separately under a stereomicroscope for the collection of endoparasites. 
After collection, all parasites were fixed in $70 \%$ alcohol and kept in glass bottles until the time of staining/clarification and assembly with a slide and coverslip. Myxozoa were gel-mounted; Monogenea were mounted in Gray \& Wess medium for the study of sclerotized structures (hooks, anchors, haptor bars, vagina and copulatory complex); Copepoda were clarified in lactic acid; Digenea and Acanthocephala were stained with carmine (Amato et al. 1991); and Nematoda were clarified with lactophenol (Eiras et al. 2006).

For parasite identification, specific bibliographies for each group with identification keys were used (Vicente et al. 1985, Lom \& Arthur 1989, Boxshall \& Montú 1997, Moravec 1998, Vicente \& Pinto 1999, Gibson et al. 2002, Kabata 1992, Boeger \& Vianna 2006, Thatcher, 2006; Cohen \& Kohn 2007, Kohn et al. 2007).

\section{Statistical analysis}

Quantitative analyses for the characterization of infrapopulations and infracommunities were obtained through calculations of prevalence, mean abundance and mean intensity, as described Bush et al. (1997).

The community status of parasite species was classified according to Bush \& Holmes (1986), classifying central species as presenting in $66 \%$ or more hosts, with secondary species present in between $33 \%$ and $65 \%$ of hosts and satellite species in fewer than $33 \%$ of hosts.

The structure of the parasitic community with prevalence equal to or greater than $10 \%$ was analyzed through its composition, numerical abundance, constancy of occurrence and species distribution, through the Pielou equitability index $\left(\mathrm{J}^{\prime}\right)$, Brillouin diversity index (HB) and Margalef richness index (d) (Ludwig \& Reynolds 1988).

The spatial distribution pattern of infrapopulations was calculated using the dispersion index (DI) and significance was tested using the statistical test $d$. The Green index (GI) was also applied to show how aggregated populations were (Ludwig \& Reynolds 1988). These indexes were only calculated for species with a prevalence equal to or greater than $10 \%$.

A species accumulation curve was run to verify sampling efficiency in conjunction with the first order Jackknife estimator (Magurran 1988) to determine the expected parasitic richness for the hosts studied. The levels of similarity between the communities of the two stretches were analyzed through the percentage similarity and Sorensen indexes (Wolda 1981).

\section{Results}

Fifty specimens of $P$. lineatus were collected and analyzed (37 from Stretch 1 and 13 from Stretch 2), with 12 females and 38 males. The hosts presented a mean standard length and weight of $28.45 \pm 6.24 \mathrm{~cm}$ and $671.48 \pm 542.74 \mathrm{~g}$ respectively. Of these 50 hosts, 875 specimens of parasites belonging to seven groups were collected: Myxozoa, Monogenea, Digenea, Nematoda, Acanthocephala, Copepoda and Hirudinea.

We found 30 parasite species (Table 1). The class Monogenea was the most representative (13 species, including a new species not yet described), followed by the Digenea subclass (six species) and by the Nematoda phylum (four species). The main site of infestation was the gills, parasitized by Myxozoa, Monogenea and Copepoda, followed by the body surface, parasitized by Monogenea, Digenea, Nematoda and
Hirudinea and the intestine, parasitized by Digenea, Acanthocephala and Nematoda.

The most prevalent species were Myxobolus sp. (58\%) and Neoechinorhynchus curemai Noronha, 1973 (56\%), followed by Diplostomidae gen. sp. (28\%) and Tereancistrum sp. n. (26\%). Regarding mean abundance, the great majority of species presented low indexes, where the only exceptions were $N$. curemai (4.62) and Tereancistrum sp. n. with mean abundance of 16.04. Regarding the mean intensity, the highest indexes were for Annelamphistoma sp. (23.00) and Tereancistrum sp. n. (13.23). Regarding the community status, 28 species were classified as satellite, since they had low prevalence, and two species were classified as secondary (Myxobolus sp. and $N$. curemai). Dispersion and Green indexes of the parasites with prevalence above $10 \%$ indicated an aggregate distribution pattern for all species (DI $>1$ and GI $>0$ ) (Table 2).

Adult and larval forms were observed for nematodes, digeneans and acanthocephalans. Among the nematodes, the two species of Contracaecum were in the L4 larval stage, while Procamallanus (Spirocamallanus) inopinatus Travassos, Artigas \& Pereira, 1928 and Spinitectus asperus Travassos, Artigas \& Pereira, 1928 were adults. Among the digeneans, Bellumcorpus sp. and Diplostomidae gen. sp. were found in the metacercarial stage, and Annelamphistoma sp., Colocladorchis sp., Unicoelium prochilodorum Thatcher \& Dossman, 2011, besides an unidentified species, were adults. Regarding the acanthocephalans, a species in the larval stage (cistacanth) was not identified, whereas the specimens of $N$. curemai were all found in the adult phase.

The accumulation curve of species showed a tendency to stabilize at 30 species, which indicates a good efficiency in parasite sampling. This can be confirmed by the first order Jackknife estimator that determined the expect richness as being 34 species, a value very close to that obtained (Figure 2).

Ecological indexes of diversity applied at the two sampling stretches showed the infracommunities of $P$. lineatus in the Batalha River as having high uniformity in the distribution of species $\left(\mathrm{J}^{\prime}=0.92\right)$ and also high richness and diversity $(\mathrm{d}=1.83$ and $\mathrm{HB}=0.81)$. Comparing the two stretches separately, Stretch 1 (Reginópolis-SP) was slightly more equitable $\left(\mathrm{J}^{\prime}=0.93\right)$ and of greater richness $(\mathrm{d}=1.96)$ (Table 3$)$. Regarding the similarity between the parasitic infracommunities at the two sampling stretches, the results obtained were relatively high, with a percentage similarity of $72.5 \%$ and a Sorensen similarity of 0.73 ; more than $70 \%$ of the parasite species were common to the two stretches of the Batalha River studied.

\section{Discussion}

This work presents the first records of the parasite biodiversity of P. lineatus in the Batalha River, where the results show a metazoan community with high species richness and low abundance. The presence of two secondary species (Myxobolus sp. and N. curemai) indicates that there is also low species dominance. This low dominance can be explained by the eating habits of the host (Lizama et al. 2005), which is essentially characterized by ingestion of detritus and sediments, which includes a large variety of invertebrates (Fugi et al. 2001). Its general diet, with low specificity of food items, makes it extremely susceptible to 
Table 1. Species, number of parasitized hosts (NPH), infestation/infection sites (IS), prevalence (P), range of variation (RV), mean abundance (MA), mean intensity (MI), community status (CS) and location of incidence (LI) of the parasites of Prochilodus lineatus from the Batalha River, Tietê-Batalha Basin, State of São Paulo, Brazil.

\begin{tabular}{|c|c|c|c|c|c|c|c|c|}
\hline Taxon & NPH & IS & $P(\%)$ & RV & MA & MI & CS & LI \\
\hline \multicolumn{9}{|l|}{ Myxozoa } \\
\hline Henneguya sp. & 8 & G & 16 & - & - & - & SA & $\mathrm{R} / \mathrm{D}$ \\
\hline Myxobolus sp. & 29 & $\mathrm{G} / \mathrm{H}$ & 58 & - & - & - & SE & $\mathrm{R} / \mathrm{D}$ \\
\hline \multicolumn{9}{|l|}{ Monogenea } \\
\hline $\begin{array}{l}\text { Kritskyia boegeri } \\
\text { Takemoto, Lizama \& Pavanelli, } 2002\end{array}$ & 1 & $\mathrm{~S}$ & 2 & 5 & $0.1 \pm 0,01$ & 5.00 & SA & $\mathrm{D}$ \\
\hline Pavanelliella sp. & 5 & $\mathrm{~N} / \mathrm{G}$ & 10 & $4-9$ & $0.68 \pm 0,04$ & $6.80 \pm 0.14$ & SA & $\mathrm{R} / \mathrm{D}$ \\
\hline $\begin{array}{l}\text { Tereancistrum ornatus } \\
\text { Karling et al., } 2014\end{array}$ & 4 & G & 8 & $1-15$ & $0.04 \pm 0,04$ & $5.00 \pm 0.08$ & SA & $\mathrm{R}$ \\
\hline $\begin{array}{l}\text { Trinibaculum altiparanae } \\
\text { Abdallah, Azevedo \& Silva, } 2013\end{array}$ & 1 & G & 2 & 1 & 0.02 & 1.00 & SA & $\mathrm{R}$ \\
\hline Phanerothecium sp. & 1 & $\mathrm{~S}$ & 2 & 3 & $0.06 \pm 0,01$ & 3.00 & SA & $\mathrm{R}$ \\
\hline $\begin{array}{l}\text { Rhinonastes pseudocapsaloideum } \\
\text { Kritsky, Thatcher \& Boeger, } 1988\end{array}$ & 7 & $\mathrm{~N}$ & 14 & $1--5$ & $0.3 \pm 0.02$ & $2.14 \pm 0.08$ & SA & $\mathrm{R} / \mathrm{D}$ \\
\hline $\begin{array}{l}\text { Rhinoxenus curimbatae } \\
\text { Domingues \& Boeger, } 2005\end{array}$ & 4 & $\mathrm{~N}$ & 8 & $1-3$ & $0.16 \pm 0.01$ & $2.00 \pm 0.05$ & SA & $\mathrm{D}$ \\
\hline Rhinoxenus sp. 1 & 7 & $\mathrm{~S}$ & 14 & $1-5$ & $0.3 \pm 0.02$ & $2.14 \pm 0.08$ & SA & $\mathrm{R} / \mathrm{D}$ \\
\hline Rhinoxenus sp. 2 & 2 & $\mathrm{~S}$ & 4 & 2 & $0,08 \pm 0,01$ & $2.00 \pm 0.02$ & SA & $\mathrm{R} / \mathrm{D}$ \\
\hline Rhinoxenus sp. 3 & 2 & $S$ & 4 & $1-6$ & $0.14 \pm 0.02$ & $3.50 \pm 0.03$ & SA & $\mathrm{R}$ \\
\hline \multicolumn{9}{|l|}{ Digenea } \\
\hline \multicolumn{9}{|l|}{ Acanthocephala } \\
\hline Cistacanth & 1 & I & 2 & 15 & $0.3 \pm 0.04$ & 15.00 & SA & $\mathrm{R}$ \\
\hline $\begin{array}{l}\text { Neoechinorhynchus curemai } \\
\text { Noronha, } 1973\end{array}$ & 28 & $\begin{array}{l}\text { ST } \\
\text { I }\end{array}$ & 56 & $1-32$ & $4.62 \pm 0.15$ & $8.25 \pm 0.91$ & SE & $\mathrm{R} / \mathrm{D}$ \\
\hline \multicolumn{9}{|l|}{ Nematoda } \\
\hline Contracaecum sp. 1 & 3 & I & 6 & $1-5$ & $0.18 \pm 0.02$ & $3.00 \pm 0.05$ & SA & $\mathrm{R} / \mathrm{D}$ \\
\hline Contracaecum sp. 2 & 4 & $\mathrm{~S}$ & 8 & 1 & $0.08 \pm 0.01$ & $1.00 \pm 0.04$ & SA & $\mathrm{R} / \mathrm{D}$ \\
\hline $\begin{array}{l}\text { Procamallanus (S.) inopinatus } \\
\text { Travassos, Artigas \& Pereira, } 1928\end{array}$ & 5 & I & 10 & $1-2$ & $0.12 \pm 0.01$ & $1.20 \pm 0.05$ & SA & $\mathrm{R} / \mathrm{D}$ \\
\hline $\begin{array}{l}\text { Spinitectus asperus } \\
\text { Travassos, Artigas \& Pereira, } 1928\end{array}$ & 10 & $\begin{array}{l}\text { ST } \\
\text { I }\end{array}$ & 20 & $1-5$ & $0.82 \pm 0.04$ & $4.10 \pm 0.18$ & SA & $\mathrm{R} / \mathrm{D}$ \\
\hline \multicolumn{9}{|l|}{ Copepoda } \\
\hline $\begin{array}{l}\text { Amplexibranchius bryconis } \\
\text { Thatcher \& Paredes, } 1985\end{array}$ & 11 & G & 22 & $1-5$ & $0.52 \pm 0.03$ & $2.36 \pm 0.13$ & SA & $\mathrm{R} / \mathrm{D}$ \\
\hline \multicolumn{9}{|l|}{ Hirudinea } \\
\hline Helobdella sp. & 11 & $\mathrm{~S}$ & 22 & $1-5$ & $0.36 \pm 0.02$ & $1.64 \pm 0.11$ & SA & $\mathrm{R} / \mathrm{D}$ \\
\hline
\end{tabular}


Leite, L.A.R. et al.

Table 2. Dispersion index (DI), statistic test $\boldsymbol{d}$ and Green index (GI), of the parasites of Prochilodus lineatus from the Batalha River, Tietê-Batalha River Basin, State of São Paulo, Brazil, with prevalence of more than $10 \%$.

\begin{tabular}{lccc}
\hline Species & DI & $\boldsymbol{d}$ & GI \\
\hline Pavanelliella sp. & 6.87 & 16.1 & 0.11 \\
Tereancistrum sp. n. & 62.07 & 68.14 & 0.04 \\
Rhinonastes pseudocapsaloideum & 2.76 & 6.58 & 0.04 \\
Rhinoxenus sp. 1 & 3.03 & 7.18 & 0.11 \\
Bellumcorpus sp. & 3.44 & 15.11 & 0.15 \\
Diplostomidae gen. sp. & 6.35 & 23.71 & 0.11 \\
Neoechinorhynchus curemai & 11.49 & 1.17 & 0.21 \\
Procamallanus (S.) inopinatus & 1.24 & 19.6 & 0.001 \\
Spinitectus asperus & 4.37 & 9.41 & 0.07 \\
Amplexibranchius bryconis & 3.79 & 4.97 & 0.06 \\
Helobdella sp. & 2.24 & 0.03 & \\
\hline
\end{tabular}

DI: $>1$ = aggregate distribution; $d: \geq 1.96=$ aggregate distribution; $d: \leq 1.96=$ aleatory distribution; GI: $>0=$ aggregate distribution (the higher the value, the greater the degree of aggregation); GI: $=0=$ aleatory distribution.

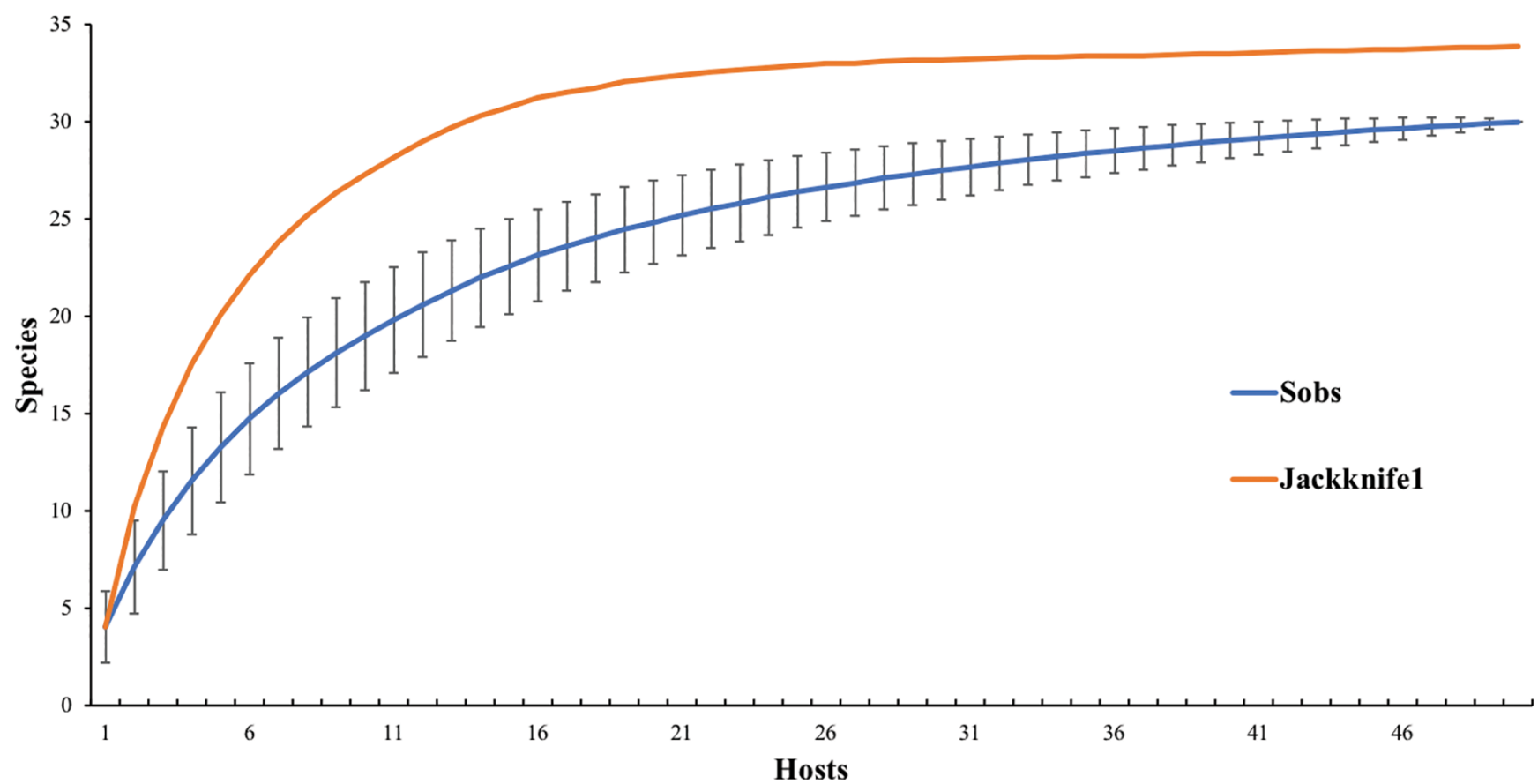

Figure 2. Accumulation curve of observed species richness (Sobs) and first-order Jackknife richness estimator (Jackknife1) of the parasites of Prochilodus lineatus from the Batalha River, Tietê-Batalha River Basin, State of São Paulo, Brazil.

Table 3. Averages and standard deviation of the ecological diversity indexes of the parasitic infracommunities of Prochilodus lineatus at both stretches (Stretch 1 - Reginópolis-SP and Stretch 2 - Piratininga-SP) sampled from the Batalha River, Tietê-Batalha River Basin, State of São Paulo, Brazil.

\begin{tabular}{lccc}
\hline Indexes & Stretch 1 & Stretch 2 & $\begin{array}{c}\text { Stretch 1 and } \\
\text { Stretch 2 }\end{array}$ \\
\hline J' & $0.93 \pm 0.13$ & $0.88 \pm 0.10$ & $0.92 \pm 0.13$ \\
d & $1.96 \pm 0.69$ & $1.49 \pm 0.71$ & $1.83 \pm 0.72$ \\
HB & $0.80 \pm 0.32$ & $0.84 \pm 0.38$ & $0.81 \pm 0.33$ \\
\hline
\end{tabular}

$\overline{\mathrm{J}}$ ' = Pielou equitability index; $\mathrm{d}=$ Margalef richness index; $\mathrm{HB}=$ Brillouin diversity index. infection/infestation by numerous parasite species (Lizama et al. 2005), which may also explain the high parasite abundance found in this fish.

The parasitic fauna of $P$. lineatus consisted mainly of ectoparasites, particularly monogeneans. It is known that Characiformes fishes have a higher abundance of parasite species in this class (Boeger \& Vianna 2006), where the presence of morphological adaptations, such as eggs with adhesive appendages that allow attachment to the substrate (Yamada et al. 2007), facilitate infestation by these parasites. Direct life cycle parasites, such as monogeneans, are most often found in lentic environments, since transmission is facilitated in low water flow environments (Lizama et al. 2006, Yamada et al. 2007, Pavanelli 
et al. 2008). The great majority of the $P$. lineatus specimens used in the present study were collected in a lotic stretch of the Batalha River, and those from a lentic environment (Stretch 2) presented a low prevalence of monogenetic parasitism. However, since migratory habits are a major characteristic of this species (Resende et al. 1996), it is assumed that it can move through different habitats and areas that have different structural characteristics, including wetlands and dams, and consequently is exposed to high parasitic richness (Caro et al. 1997).

The aggregate distribution pattern observed in the metazoan parasite community of $P$. lineatus in the present study followed the same pattern observed for the metazoan community of the same host species in other rivers of the Upper Paraná River Basin (Bruno 2003, Lizama et al. 2005). According to Zuben (1997), the main factors that generate an aggregate distribution of parasites in the host are mainly associated with random environmental variables, including changes in physical parameters of the environment (including both host and habitat) that, according to Anderson \& Gordon (1982), includes: (1) heterogeneity in host susceptibility to infection/infestation, (2) direct reproduction of the parasite within the host and (3) heterogeneity in the hosts ability to eliminate parasites by immunological response or other types of response. Further, according to Zuben (1997), the aggregate pattern of distribution commonly found among different species of parasites contributes to community stability, minimizing the frequency of interspecific interactions between parasites, thus allowing intraspecific regulation mechanisms to dominate. Thus, competitive interactions among different species of parasites will influence only small proportions of each parasitic population present in simultaneously infected hosts.

Regarding endoparasites, digeneans constituted the second largest group of species, reflecting the already expected pattern for diversity in freshwater fish parasites in Brazil (Eiras et al. 2011, Cribb et al. 2002). Of the six species found, two were in the larval stage (metacercarie) (Bellumcorpus sp. and Diplostomidae gen. sp.) and only one could be identified to species level (U. prochilodorum). According to Niewiadomska \& Niewiadomska-Bugaj (1995), the difficulty in identifying species of this subclass, particularly metacercariae, is due to variation in morphology and also to the limited number of morphological differences. Among the factors that cause variation in the morphology of these parasites are the host fish species, the density of the infection and the size and maturation stage of the host. Any of these factors can generate significant differences between individuals of the same digenean species. Another factor that may influence identification are the methodologies used for fixation, preservation and analysis of the parasites, with the use of molecular biology being a safer way to obtain accurate results regarding the identification of the species (Zago 2016). The high prevalence of Diplostomidae gen. sp. parasitizing the host's eyes has previously been reported in several species of fish in the Upper Paraná River Basin (Takemoto et al. 2009). Parasitism by diplostomids can cause severe ocular pathologies such as blindness and cataracts, impairing fish eyes and making then more susceptible to predation by piscivorous birds, which act as definitive hosts for these parasites to complete their life cycle (Pavanelli et al. 2008).

Two species of acanthocephalans were collected, but only one can be identified to the lowest taxonomic level. Neoechinorhynchus curemai is a parasite commonly found parasitizing P. lineatus (Martins et al. 2001b), and in the present study it was the second most prevalent parasite, collected in $56 \%$ of the hosts, being the only species characterized with secondary community status. It has been proven that parasitism by $N$. curemai can cause several tissue changes in the host intestine, including hyperplasia and hypertrophy of goblet cells, as well as severe inflammation and edema in the intestinal mucosa (Martins et al. 2001a).

Three of the four species of parasitic nematodes found had low prevalence and abundance; only $S$. asperus had a prevalence above $20 \%$. The low occurrence of parasitic nematodes in P. lineatus has been reported previously, ranging from one to at most four species (Lizama et al. 2005, Zago 2016). High specificity with respect to the definitive host (Moravec 1998) and even competition with other parasites (Dobson 1985) may contribute to the relatively low abundance and richness of the infrapopulations of these parasites.

Despite the low prevalence and abundance of nematodes in $P$. lineatus, one should consider the zoonotic potential that some of these nematode species have, particularly anisakids, such as those in the genus Contracaecum. Despite the limited cases reported in humans, experimental studies in terrestrial mammals confirm the susceptibility to infection and the high zoonotic potential of the genus (Vidal-Martínez et al. 1994, Buchmann \& Mehrdrama 2016). In addition, larvae of Contracaecum sp. have proven to be an excellent accumulator of toxic metals, and can be considered as good indicators of pollution, and therefore deserve attention (Leite et al. 2017).

Regarding copepods, Amplexibranchius bryconis Thatcher \& Paredes, 1985 had previously been reported parasitizing P. lineatus (Abdallah et al. 2011), and as before, and, as before, this crustacean parasite when present was recorded as having an epibiotic association with the host. In addition, parasitism by ergasilids may cause partial or complete occlusion of the lamella blood vessel, hyperplasia and increased mucus production, causing a decrease in the respiratory capacity of the host and causing secondary infections (Pavanelli et al. 2008).

In general, relatively little is known about the biodiversity of the parasitic fauna of $P$. lineatus, with only a handful of studies conducting extensive surveys (Lizama et al. 2005, Takemoto et al. 2009, Côrrea 2014). The other existing studies on this host focus on specific taxa and the description of new species, especially for myxozoans and monogenetics (Adriano et al. 2002, Takemoto et al. 2002, Bruno 2003, Adriano 2005, Cugliana et al. 2009, Campos et al. 2011, Azevedo et al. 2014). In the present study, in addition to new records of known parasites for $P$. lineatus previously, 13 species were newly recorded parasitizing this fish (Demidospermus paravalenciennesi Gutiérrez \& Suriano, 1992, Pavanelliella sp., Tereancistrum ornatus Karling et al., 2014, Trinibaculum altiparanae Abdallah, Azevedo \& Silva, 2013, Phanerothecium sp., Rhinoxenus sp. 1, Rhinoxenus sp. 2, Rhinoxenus sp. 3, Annelamphistoma sp., Bellumcorpus sp., Diplostomidae gen. sp., and $P$. (S.) inopinatus), in addition to the record of a new monogenean species (Tereancistrum sp. n.). This expands the geographical distribution of known parasite species of $P$. lineatus and assists in increasing our knowledge of the biodiversity of these organisms in different hosts and environments.

In relation to the similarity indexes (percentage and Sorensen), the values obtained can be considered high, revealing high similarity between the parasite communities in the hosts collected in the two stretches, despite being two structurally distinct environments 
(lagoon $=$ lentic and river channel $=$ lotic). According to Poulin \& Morand (2004), the geographic distance between the ichthyo parasitological communities of the same host species is often the best predictor of similarity in species composition. Although the distance between the collection sites is relatively large $(135 \mathrm{~km}), P$. lineatus is a species that performs long upstream migrations, preceded by annual floods (Stassen et al. 2010), this being the predominant factor explaining such similarity. The same can also be applied to the richness, diversity and equitability indexes, which were stable at both stretches, when it was expected that there would be significant differences between the values since these are environments with different characteristics, especially when regarding the physical and chemical characteristics of water, which, according to Galli et al. (2001), are determining factors in the composition of the parasitic communities of fish.

\section{Conclusion}

The structure and composition of the $P$. lineatus parasitic fauna did not seem to be influenced by the structural characteristics of the two stretches studied, due to the migratory habits of the host. In addition, the present work contributes significantly to the knowledge about the biodiversity of the $P$. lineatus parasites in the Batalha River, a region that has not been explored so far, helping to expand the knowledge about the parasitic fauna of Brazilian fish in different ecosystems, filling some of the existing gaps in this field and contributing to the registration of new species not yet described by science.

\section{Acknowledgments}

The authors would like to thank Academic and Scientific Proofreading and Editing Services for editing the English. Rodney K. de Azevedo was supported by a Research fellowship from Fundação de Amparo à Pesquisa do Estado de São Paulo - Fapesp (2014/12862-0) and Vanessa D. Abdallah was supported by a Research fellowship from Fapesp (2012/23655-0). Lucas A. R. Leite and Larissa S. Pelegrini were supported by a student fellowship from Coordenação de Aperfeiçoamento de Pessoal de Nível Superior - CAPES.

\section{Author Contributions}

Lucas Aparecido Rosa Leite: Substantial contribution in the concept and design of the study. Contribution to data collection. Contribution to data analysis and interpretation. Contribution to manuscript preparation.

Contribution to critical revision, adding intelectual contente.

Larissa Sbeghen Pelegrini: Contribution to data collection. Contribution to data analysis and interpretation. Contribution to manuscript preparation. Contribution to critical revision, adding intelectual contente.

Beatriz Narciso Agostinho: Contribution to manuscript preparation.

Rodney Kozlowiski de Azevedo: Contribution to data collection. Contribution to critical revision, adding intelectual contente.

Vanessa Doro Abdallah: Substantial contribution in the concept and design of the study. Contribution to data analysis and interpretation. Contribution to critical revision, adding intelectual contente.

\section{Conflicts of interest}

The authors declare that they have no conflict of interest related to the publication of this manuscript.

\section{References}

ABDALLAH, V.D., AZEVEDO, R.K. \& SILVA, R.J. 2011. First Record of an epibiont protozoan Epistylis sp. (Ciliophora, Peritrichia) attached to Amplexibranchius bryconis Thatcher \& Paredes, 1985 (Copepoda, Ergasilidae) from Peixe's River, State of São Paulo, Brazil. Crustaceana, 84(9): 1139-1144.

ADRIANO, E.A., ARANA, S., CECCARELLI, P.S. \& CORDEIRO, N.S. 2002. Light and scanning electron microscopy of Myxobolus porofilus sp. n. (Myxosporea: Myxobolidae) infecting the visceral cavity of Prochilodus lineatus (Pisces: Characiformes: Prochilodontidae) cultivated in Brazil. Fol. Parasitol., 49(4): 259-262.

ADRIANO, E.A., ARANA, S. \& CORDEIRO, N.S. 2005. Histophatology and ultrastructure of Henneguya caudalongula sp. n. infecting Prochilodus lineatus (Pisces: Prochilodontidae) cultivated in the state of São Paulo, Brazil. Mem. Inst. Oswaldo Cruz, 100(2):177-181.

AMATO, J.F.R., BOEGER, W.A. \& AMATO, S.B. 1991. Protocolos para laboratório coleta e processamento de parasitos do pescado. Imprensa Universitária, Universidade Federal Rural do Rio de Janeiro, Soropédica.

ANDERSON, R.M. \& GORDON, D.M. 1982. Processes influencing the distribution of parasite numbers within host populations with special emphasis on parasite-induced host mortalities. Parasitology, 85: 373-398.

AZEVEDO, R.K., VIEIRA, D.H., VIEIRA, G.H., SILVA, R.J., MATOS, E. \& ABDALLAH, V.D. 2014. Phylogeny, ultrastructure and histopathology of Myxobolus lomi sp. nov., a parasite of Prochilodus lineatus (Valenciennes, 1836) (Characiforme: Prochilodontidae) from the Peixes River, São Paulo State, Brazil. Parasitol. Int., 63(2): 303-307.

BOEGER, W.A. \& VIANNA, R.T. 2006. Monogenoidea. In: Thatcher, V.E. (Ed). Amazon Fish Parasites. Pensoft Publishers, Sofia, p. 42-116.

BOXSHALL, G.A. \& MONTÚ, M. 1997. Copepods parasitic on Brazilian coastal fishes: a handbook. Nauplius, 5(1): 1-225.

BRASIL. Ministério do Meio Ambiente. Resolução CONOMA nº 357, de 17 de março de 2005. Brasília, 2005. Dispõe sobre a classificação dos corpos de água e diretrizes ambientais para o seu enquadramento, bem como estabelece as condições e padrões de lançamento de efluentes, e dá outras providências. http://www.mma.gov.br/port/conama/res/res05/res35705.pdf (last acess: 23/09/2016).

BRUNO, A.M.C.P. 2003. Taxonomia e aspectos quantitativos dos monogeneos (Platyhelminthes: Monogenea) parasitos de Prochilodus lineatus (Prochilodontidae) e de Bryconcephalus (Characidae) de tanques de piscicultura. (Dissertação: Mestrado em Biologia Animal) - Universidade Estadual de Campinas, Campinas.

BUCHMANN, K. \& MEHRDANA, F. 2016. Effects of anisakid nematodes Anisakis simples (s.1.), Pseudoterranova decipiens (s.1) and Contracaecumosculatum (s.1.) on fish and consumer health. Food Water Parasitol., 1-10.

BUSH, A.O., LAFFERTY, K.D., LOTZ, M.J. \& SHOSTAK, A.W. 1997. Parasitology meets ecology on its own terms: Margolis et al. revisited. J. Parasitol., 83: 575-583.

BUSH, A.O. \& HOLMES, J.C. 1986. Intestinal helminths of lesser scaup ducks: an interactive community. Can. J. Zool., 64: 142-152.

CAMPOS, C.M., MORAES, J.R.E. \& MORAES, F.R. 2011. Histopathology of gills of Piaractus mesopotamicus (Holmberg, 1887) and Prochilodus lineatus (Valenciennes, 1836) infested by monogenean and myxosporea, caught in Aquidauana River, State of Mato Grosso do Sul, Brazil. Rev. Bras. Prasitol. Vet., 20(1): 67-70.

CARO, A., COMBES, C. \& EUZET, L. 1997. What makes a fish a suitable host for Monogenea in the Mediterranean? J. Helminthol., 71: 203-210. 
CASTRO, R.M.C. \& MENEZES, N.A. 1996. Estudo da diversidade de peixes do Estado de São Paulo. Ribeirão Preto: Trabalho não publicado, 11 p.

COHEN, S.C. \& KOHN, A. 2008. South American Monogenea: List of species, hosts and geographical distribution from 1997 to 2008. Zootaxa, 1924(1): $1-42$.

CORRÊA, L. L. 2014. Parasitos de Prochilodus lineatus, Hoplias aff. malabaricus e Clarias gariepinus das bacias dos rios Grande e MogiGuaçu, Estado de São Paulo. Tese (Doutorado em Parasitologia) Universidade Estadual de Campinas, Campinas.

CRIBB, T.H., CHISHOLM, L.A. \& BRAY, R.A. 2002. Diversity in the Monogenea and Digenea: does lifestyle matter? Int. J. Parasitol., 32: 321-328.

CUGLIANNA, A.M., CORDEIRO, N.S. \& LUQUE, J.L. 2009. Apenduculata discoidea gen. n., sp. n. (Monogenea: Dactylogyridae) parasitic on Prochilodus lineatus (Valenciennes, 1837) (Characiformes: Prochilodontidae) from southeastern Brazil. Braz. J. Biol., 69(3): 895-898.

DEPARTAMENTO DE ÁGUA E ESGOTO DE BAURU. Rio Batalha e a Lagoa, 2014. http://www.daebauru.com.br/2014/empresa/empresa.php (last acess: 25/09/2016).

DOBSON, A.P. 1985. The population dynamics of competition between parasites. Parasitology, 91: 317-347.

EIRAS, J.C., TAKEMOTO, R.M., PAVANELLI, G.C. \& ADRIANO, E.A. 2011. About the biodiversity of parasites of freshwater fish from Brazil. Bull. Eur. Ass. Fish Pathol., 31 (4): 161-168.

EIRAS, J.C., RANZANI-PAIVA, M.J.T., ISHIKAWA, C.M. \& ALEXANDRINO, A.C. 1995. Ectoparasites of semi-intensively farmed tropical freshwater fish Piaractus mesopotamicus, Prochilodus lineatus and Colossoma macropomum in Brazil. Bull. Eur. Ass. Fish Pathol., 15: 148-151.

EIRAS, J.C., PAVANELLI, G.C. \& TAKEMOTO, R.M. 2004. Henneguya paranaensis sp. n. (Myxozoa, Myxobolidae), a parasite of the teleost fish Prochilodus lineatus (Characiformes, Prochilodontidae) from the Paraná River, Brazil. Bull. Eur. Ass. Fish Pathol., 24: 308-311.

EIRAS, J.C., TAKEMOTO, R.M. \& PAVANELLI, G.C. 2006. Métodos de estudo e técnicas laboratoriais em parasitologia de peixes. 2 ed. Universidade Estadual de Maringá, Maringá, 199p.

ESTADO DE SÃO PAULO. Comitê da bacia hidrográfica do Tietê Batalha: Fundamentos para implantação da cobrança pelo uso dos recursos hídricos, 2010. http://www.sigrh.sp.gov.br/public/uploads/documents/7406/ fundamentacao_cobranca_tb.pdf (last acess: 23/09/2016).

FUGI, R., AGOSTINHO, A.A. \& HAHN, N.S. 2001. Trophic morphology of five benthic-feeding fish species of a tropical floodplain. Rev. Bras. Biol., $61: 1,27-33$.

GALLI, P., CROSA, G., MARINIELLO, L., ORTIS, M. \& DÀMELIO, D. 2001. Water quality as a determinant of the composition of fish parasite communities. Hydrobiologia, 452: 173-179.

GIBSON, D.I., JONES, A. \& BRAY, R.A. 2002. Keys to the trematoda. Vol. 1. CABI Publishing, Wallingford and New York, $521 \mathrm{p}$.

GÓMEZ, A., NICHOLS, E. 2013. Neglected wild life: Parasitic biodiversity as a conservation target. Int. J. Parasitol. Parasites Wildl., 2: 222-227.

GOOGLE EARTH. Programa de localização através de imagens via satélite. Versão 7.1.2.2041, 2016. https://www.google.com.br/intl/pt-BR/earth/ (last acess: 23/09/2016)

KABATA, Z. 1992. Copepods parasitic on fishes. Universal books Service Oegstgeest, Netherlands, $264 \mathrm{p}$.

KOHN, A., FERNANDES, B.M.M. \& COHEN, S.C. 2007. South American trematodes parasites of fishes. Imprinta Express Ltda, Rio de Janeiro, $318 \mathrm{p}$.

LAFFERTY, K.D. 1997. Environmental parasitology: what can parasites tell us about human impacts on the environment? Parasitol. Today, 13: 251-255.

LAFFERTY, K.D. \& KURIS, A.M. 2005. Parasitism and environmental disturbances. In: THOMAS, F, RENAUD, F.L. \& GUÉGAN, J. (Org.) Parasitism and Ecosystems. Oxford University Press, p. 113-123.
LANGEANI, F., BUCKUP, P.A., MALABARBA, L.R., PY-DANIEL, L. R., LUCENA, C.A.S., ROSA, R.S., LUCENA, Z.M.S., BRITTO, M.R., OYAKAWA, O.T. \& GOMES-FILHO, G. 2009. Peixes de Água Doce. In: ROCHA, R.M. \& BOEGER, W.A. (Org.). Estado da Arte e Perspectivas para a Zoologia no Brasil. Ed. UFPR, Curitiba, p. 212-230.

LEITE, L.A.R., PEDRO, N.H.O., AZEVEDO, R.K., KINOSHITA, A., GENNARI, R., WATANABE, S. \& ABDALLAH, V.D. 2017. Contracaecum sp. parasitizing Acestrorhynchus lacustris as a bioindicator for metal pollution in the Batalha River, southeast Brazil. Sci. Total Environ., 575: 836-840.

LIZAMA, M.A.P., TAKEMOTO, R.M. \& PAVANELLI, G.C. 2004. New species of Tereancistrum Kritsky, Thatcher \& Kayton, 1980 (Monogenea: Dactylogyridae: Ancyrocephalinae) from the gills of Prochilodus lineatus (Osteichthyes: Prochilodontidae) from the upper Paraná River floodplain, Brazil. System. Parasitol., 57(1): 45-49.

LIZAMA, M.A.P., TAKEMOTO, R.M. \& PAVANELLI, G.C. Influence of host sex and age on infracommunities of metazoan parasites of Prochilodus lineatus (Valenciennes, 1836) (Prochilodontidae) of the Upper Paraná River floodplain, Brazil. Parasite, 12(4): 299-304, 2005.

LIZAMA, M.A.P., TAKEMOTO, R.M. \& PAVANELLI, G.C. 2006. Influence of the Seasonal and Environmental Patterns and Host Reproduction on the Metazoan Parasites of Prochilodus lineatus. Braz. Arch. Biol. Technol. 49(4): 611-622.

LOM, J. \& ARTHUR, J.R.A. 1989. Guideline for the preparation of species descriptions in Myxosporea. J. Fish. Dis., 12: 151-156.

LOWE-MCCONELL, R.H. 1999. Estudos Ecológicos de Comunidade de Peixes Tropicais. Edusp, São Paulo, 535 p.

LUDWIG, J.A.; REYNOLDS, J.F. 1988. Statistical Ecology: A Primer on Methods and Computing. Princeton University Press, New Jersey, 337 p.

MAGURRAN, A.E. 1988. Ecological diversity and its measurement. Princeton University Press, New Jersey, 167 p.

MARTINS, M.L., MORAES, J.R.E., ANDRADE, P.M., SCHALCH, S.H.C. \& MORAES, F.R. 2001a. Piscinoodinium pillulare (Schäperclaus, 1954) Lom, 1981 (Dinoflagellida) infection in cultivated freshwater fish from the Northeast region of São Paulo State, Brazil: parasitological and pathological aspects. Braz. J. Biol., 61(4): 639-644.

MARTINS, M.L., MORAES, F.R., FUJIMOTO, R.Y., ONAKA, E.M. \& QUINTANA, C.I.F. 2001b. Prevalence and histopathology of Neoechinorhynchus curemai Noronha, 1973 (Acanthocephala: Neoechinorhynchidae) in Prochilodus lineatus Valenciennes, 1836 from Volta Grande Reservoir, MG, Brazil. Brazil. J. Biol, 61(3): 517-522.

MARTINS, M.L., FUJIMOTO, R.Y., ANDRADE, P.M. \& TAVARES-DIAS, M. 2000. Recent studies on Neoechinorhynchus curemai Noronha, 1973 (Acanthocephala: Neoechinorhynchidae), in Prochilodus lineatus Valenciennes, 1836, from Volta Grande Reservoir, MG, Brazil. Rev. Bras. Biol., 60(4): 673-682.

MORAVEC, F. 1998. Nematodes of Freshwater Fishes of the Neotropical Region. Academia, Praga, $464 \mathrm{p}$.

NELSON, J.S. 2006. Fishes of the World. John Wiley \& Sons, New Jersey, $601 \mathrm{p}$.

NIEWIADOMSKA, K. \& NIEWIADOMSKA-BUGAJ, M. 1995. Optimal identification procedure for Diplostomum paracaudum (Iles, 1959) and $D$. pseudospathaceum Niewiadomska, 1984 metacercarie (Digenea) based on morphological characters. Sist. Parasitol., 30:165-171.

OYAKAWA, O.T., MENEZES, N.A., SHIBATTA, O.A., LIMA, F.C.T., LANGEANI, F., PAVANELLI, C.S., NIELSEN, D.T.B. \& HILSDORF, A.W.S. 2009. Peixes de Água Doce. In: BRESSAN, P.M., KIERULFF, M.C.M. \& SUGIEDA, A.M. (Coord.). Fauna Ameaçada de Extinção no Estado de São Paulo. Fundação Parque Zoológico de São Paulo, Ministério do Meio Ambiente, São Paulo, p. 349-424.

PAVANELLI, G.C., EIRAS, J.C. \& TAKEMOTO, R.M. 2008. Doenças de peixes: profilaxia, diagnóstico e tratamento. 3 ed. EDUEM, Maringá, 311 p. 
POULIN, R. \& MORAND, S. 2004. Parasite Biodiversity. Smithsonian Books, Washington, $216 \mathrm{p}$.

RESENDE, E.K., CATELLA, A.C., NASCIMENTO, F.L., PALMEIRA, S.S., PEREIRA, R.A.C., LIMA, M.S. \& ALMEIDA, V.L.L. 1996. Biologia do curimbatá (Prochilodus lineatus), pintado (Pseudoplatystoma corruscans) e cachara (Pseudoplatystoma fasciatum) na bacia hidrográfica do rio Miranda, Pantanal do Mato Grosso do Sul, Brasil. EMBRAPA-CPAP, Corumbá, 75 p.

ROSA, R.S. \& LIMA F.C.T. 2008. Os Peixes Brasileiros Ameaçados de Extinção. In: BRESSAN, P.M., KIERULFF, M.C.M. \& SUGIEDA, A.M.S. (Org.). Fauna Ameaçada de Extinção no Estado de São Paulo. Fundação Parque Zoológico de São Paulo: Secretaria do Meio Ambiente, São Paulo, p. 9-275.

RULL, V. Neotropical biodiversity: timing and potential drivers. Trends Ecol. Evol., 26, (10): 508-513, 2011.

SANTOS, F.S. \& HEUBEL, M.T.C.D. 2008. Composição da comunidade ictiológica e biometria taxológica na lagoa de captação de água do DAE no rio Batalha (Bauru-SP). Salusvita, 27(1): 29-44.

SANTOS, R.S., MARTINS, M.L., MARENGONI, N.G., FRANCISCO, C.J., PIAZZA, R.S., TAKAHASHI, H.K. \& ONAKA, E.M. 2005. Neoechinorhynchus curemai (Acanthocephala: Neoechinorhynchidae) in Prochilodus lineatus (Osteichthyes: Prochilodontidae) from the Paraná River, Brazil. Vet. Parasitol., 134(1): 111-115.

SILVA-SOUZA, A.T., SHIBATTA, O.A., MATSUMURA-TUNDISI, T., TUNDISI, J.G. \& DUPAS, F.A. 2006. Parasitos de peixes como indicadores de estresse ambiental e eutrofização. In: TUNDISI, J.G., MATSUMURATUNDISI, T. \& SIDAGIS GALLI, C. (Org.). Eutrofização na América do Sul: causas, consequências e tecnologias para gerenciamento e controle. 1 ed. Instituto Internacional de Ecologia, São Carlos, p. 373-386.

SISTEMA NACIONAL DE INFORMAÇÕES SOBRE SANEAMENTO. Série histórica: informações sobre água e esgoto dos municípios brasileiros, 2016. http://app.cidades.gov.br/serieHistorica/\# (last acess: 23/09/2016.

STASSEN, M.J.M., VAN DE VEN, M.W.P.M., VAN DER HEIDE, T., HIZA, M.A.G., VAN DER VELDE, G. \& SMOLDERS, A.J.P. 2010. Population dynamics of the migratory fish Prochilodus lineatus in a neotropical river: the relationships with river discharge, flood pulse, El Niño and fluvian megafan behavior. Neotrop. Ichthyol., 8: 113-122.

SURES, B. 2008. Environmental Parasitology: Interactions between parasites and pollutants in the aquatic environment. Parasite, 15: 434-438.
TAKEMOTO, R.M., PAVANELLI, G.C., LIZAMA, M.A.P., LACERDA, A.C.F., YAMADA, F.H., MOREIRA, L.H.A., CESCHINI, T.L. \& BELLAY, S. 2009. Diversity of parasites of fish from the Upper Paraná River floodplain, Brazil. Braz. J. Biol., 6(2): 691-705.

TAKEMOTO, R.M., LIZAMA, M.A.P. \& PAVANELLI, G.C. 2002. A new species of Kritskyia (Dactylogyridae, Ancyrocephalinae) parasite of urinary bladder of Prochilodus lineatus (Prochilodontidae, Characiformes) from the floodplain of the high Paraná river, Brazil. Mem. Inst. Oswaldo Cruz, 97(3): 313-315.

THATCHER, V.E. (Ed.). 2006. Amazon Fish Parasites. Pensoft Publishers, Sofia, $496 \mathrm{p}$.

VALLADÃO, G.M.R., GALLNI, S.U., DE PÁDUA, S.B., MARTINS, M.L. \& PILARSKI, F.2014. Trichodina heterodentata (Ciliophora) infestation on Prochilodus lineatus larvae: a host-parasite relationship study. Parasitology, 141(05): 662-669.

VICENTE, J.J. \& PINTO, R.M. 1999. Nematóides do Brasil: Nematóides de peixes. Atualização 1985-1998. Rev. Bras. Zoo., 16(3): 561-610.

VICENTE, J.J., RODRIGUES, H.O. \& GOMES, D.C. 1985. Nematóides do Brasil. $1^{a}$ parte: Nematóides de peixes. Atas Soc. Biol. Rio de Janeiro, 25: 1-79.

VIDAL-MARTÍNEZ, V.M., OSORIO-SARABIA, D. \& OVERSTREET, R. M. 1994. Experimental infection of Contracaecum tipapillatum (Nematoda: Anisakinae) from Mexico in the domestic cat. J. Parasitol., 80: 156-166.

YAMADA, F.H., TAKEMOTO, R.M., PAVANELLI, G.C. 2007. Ecological aspects of ectoparasites from the gills of Satonoperca pappaterra (Heckel, 1840) (Cichlidae) from the upper Paraná river floodplain, Brazil. Acta Sci. Biol. Sci., 29(3), 331-336.

ZAGO, A.C. 2016. Biodiversidade dos parasitas de peixes provenientes do rio Sapucaí-Mirim, Estado de São Paulo, Brasil. Tese (Doutorado em Ciências Biológicas - Zoologia) - Universidade Estadual Paulista “Júlio de Mesquita Filho", Botucatu.

ZUBEN, C.J.V. 2007. Implicações da agregação espacial de parasitas para a dinâmica populacional na interação hospedeiro-parasita. Rev. SaúdePúbl., 31(5): 523-30.

WOLDA, H. 1981. Similarity Indices, Sample Size and Diversity. Oecol., 50: 296-302.

Received: 07/08/2017

Revised: 05/06/2018

Accepted: 12/06/2018

Published online: 16/07/2018 